\title{
EVALUASI REKRUTMEN PENGAWAS TEMPAT PEMUNGUTAN SUARA (PTPS) DALAM PEMILU SERENTAK 2019
}

\author{
Faisal Andri Mahrawa \\ Dosen IImu Politik Fakultas IImu Sosial dan IImu Politik \\ Universitas Sumatera Utara (USU), Medan, Sumatera Utara, Indonesia \\ faisal.mahrawa@gmail.com \\ Irfan Prayogi \\ Alumni IImu Politik Fakultas IImu Sosial dan IImu Politik Universitas Sumatera \\ Utara, Medan, Sumatera Utara, Indonesia \\ irfanprayogi44@yahoo.com
}

\begin{abstract}
This paper is intended to examine the recruitment pattern carried out by Bawaslu to bring PTPS to the 2019 Simultaneous Elections. The research location was conducted in two regions namely Sunggal District and Percut Sei Tauan District, Deliserdang Regency. By understanding various aspects ranging from the regulatory side to the technical implementation of recruitment, found various obstacles that resulted in the quality of PTPS, ranging from age limits, educational boundaries, community enthusiasm to regional factors that cause PTPS presented less professional. Using the descriptiveanalysis method, data sources were collected through interviews and literature studies related to the PTPS recruitment process. As an evaluation and recommendation, this paper reviews several aspects, namely regulation, promotion and outreach, provision of intensive supervision functions, and transparency of recruitment to be considered in welcoming the next election
\end{abstract}

Keywords: bawaslu, evaluation, ptps, recrutment 


\begin{abstract}
Abstrak
Tulisan ini dimaksudkan untuk mengkaji pola rekrutmen yang dilakukan Bawaslu untuk menghadirkan PTPS pada Pemilu Serentak 2019. Adapun lokasi penelitian dilakukan di dua daerah yakni Kecamatan Sunggal dan Kecamatan Percut Sei Tauan, Kabupaten Deliserdang. Dengan memahami berbagai aspek mulai dari sisi regulasi hingga teknis pelaksanaan rekrutmen, ditemukan berbagai kendala yang berakibat pada kualitas PTPS, mulai dari batas usia, batas pendidikan, antusiasme masyarakat hingga faktor wilayah yang menyebabkan PTPS yang dihadirkan kurang profesional. Menggunakan metode analisis-deskriptif, sumber data dikumpulkan melalui proses wawancara dan studi literatur terkait dengan proses rekrutmen PTPS. Sebagai evaluasi dan rekomendesi, tulisan ini meninjau beberapa aspek yakni regulasi, promosi dan sosialisasi, pembekalan fungsi pengawasan intensif, dan transparansi rekrutmen untuk diperhatikan dalam menyambut pemilu berikutnya.
\end{abstract}

Kata Kunci : bawaslu, evaluasi, ptps, rekrutmen

\section{Pendahuluan}

Institusi pengawas Pemilu menjadi solusi yang dianggap tepat menangani permasalahan ini. Sebagai wujud kongktitnya, dalam UU No. 17 Tahun 2017 tentang Pemilihan Umum kedudukan Badan Pengawas Pemilu (Bawaslu) di perkuat dan diperjelas secara fungsi dan tugas sebagai penyelenggara Pemilu. ${ }^{1}$ Bawaslu untuk pertama kali dalam sejarah memiliki kewenangan mengawasi TPS dengan membentuk Pengawas Tempat Pemungutan Suara yang selajutnya disebut PTPS. Pilkada Serentak 2018 dan Pemilu Serentak 2019 menjadi pesta demokrasi yang melibatkan PTPS dalam

1 Dalam UU No 7 Tahun 2017 disebutkan bahwa Badan Pengawas Pemilu Tingkat KabupatenKota telah bersifat tetap. Setidaknya ada 11 kewenangan yang melekat yang diamanahkan oleh UndangUndang tersebut. mengawasi jalannya pemungutan suara hingga penghitungan suara.

PTPS memiliki kewajiban melaporkan hasil pengawasan dalam pemungutan suara kepada Panwascam melalui Panwaslu Desa/kelurahan. Selain itu, PTPS berwenang untuk menyampaikan keberatam atas dugaan pelanggaran,kesalahan, penyimpangan admistrasi, dan menerima berita acara dalam penghitungan suara dengan rentang waktu selama persiapan, pelaksanaan, hingga pergerakan hasil penghitungan suara dari TPS ke PPS (UU No 17 tahun 2017: Pasal 114-116). Dengan demikian PTPS memiliki peran yang sangat strategis dalam menjaga dan mengawasi proses Pemilu agar berjalan dengan jujur dan mengedepankan asas keadilan dalam pemilu.

Sebagai formatur baru dalam kepemiluan skala nasional, otomatis kehadiran PTPS sangat membantu 
melakukan monitoring secara lebih efektif dengan jumlah yang sama dengan jumlah TPS yang ada. ${ }^{2}$ Sebelumnya dalam UU No 15 Tahun 2011 tentang Penyelenggaraan Pemilu, Bawaslu di tingkatan akar rumput membawahi Pengawas Pemilu Lapangan yang hanya bertugas mengawasi, merekomendasi, meneruskan, dan menyampaikan temuan kepada Panwascam dalam hal pelanggaran Pemilu. Hal tersebut berbeda dengan wewenang yang diamatkan oleh UU No. 7 tahun 2017, di mana Pengawas dalam tatanan akar rumput yakni PTPS sebagaimana pasal 115 boleh menyampaikan keberatan dalam hal ditemukannya dugaan pelanggaran, kesalahan dan/ atau penyimpangan administrasi pemungutan dan penghitungan suara langsung di TPS, bahkan Pengawas TPS bisa merekomendasikan agar dilakukan pemungutan suara ulang (PSU) di TPS yang bersangkutan (Rudia 24 Maret 2019).

Tetapi pada kenyataannya, kinerja PTPS masih belum efektif dalam menjalankan fungsunya dan terkesan hanya sebagai pelengkap Pemilu disamping kewenangannya yang strategis. Pola rekrutmen PTPS menjadi salah satu faktor permasalahannya. Sebagaimana diketahui, dalam pasal 106 UU No 17 Tahun 2017 PTPS dibentuk oleh Panitia Pengawas Kecamatan (Panwascam) dengan memperhatikan masukan Panwaslu Kelurahan/Desa. Adapun syarat yang ditetapkan untuk menjadi seorang PTPS secara teknis yakni minimal berusia

\footnotetext{
2 Dihimpun dari Website kpu.go.id : jumlah TPS se Indonesia sebesar 809.500 unit.
}

25 tahun, berpendidikan paling rendah SMA/Sederajat. Selain itu, calon PTPS harus memiliki kemampuan dan keahlian yang berkaitan dengan Penyelenggaraan Pemilu, ketatanegaraan, kepartaian, dan Pengawasan Pemilu.

Sebagai catatan, banyak Panwascam di daerah yang mengalami kesulitan dalam rangka merekrut PTPS terutama di daerah Pedesaan dan Pesisir yang diakibatkan persyaratan usia dan batas minimal pendidikan. Artinya, sulit mendapatkan PTPS yang sesuai dengan kualifikasi sebagaimana yang ditentukan oleh regulasi perundangundangan. Adapun PTPS dibentuk paling lambat 23 hari sebelum pemungutan suara dan dibubarkan paling lambat tujuh hari setelah hari pemungutan suara oleh Panitia Pengawas Kecamatan (Panwascam). Dalam surat edaran Bawaslu terkait pembentukan PTPS, tercatat Panwascam hanya memiliki waktu satu bulan dalam proses pelaksanaan rekrutmen, terhitung dari pengumuman pendaftaran hingga pelantikan dan Bimbingan teknis (Bawaslu.go.id: 2019).

Dikutip dari berbagai laman berita, persyaratan usia dan tingkat pendidikan sangat mendominasi kendala yang dihadapi Panwascam untuk melakukan perekrutan. Ini juga diakui oleh Ketua Bawaslu RI dalam Rapat Dengar Pendapat bersama Komisi II DPR RI. Permasalahannya adalah dengan usia yang telah ditetapkan oleh UndangUndang, seseorang pasti sudah mapan dengan pekerjaannya. Disamping juga menutup peluang kepada mahasiswa dan muda-mudi untuk berkontribusi dalam proses pengawasan pemilu akibat batasan usia yang terpaut tinggi.

Tidak dinafikkan bahwa dalam proses 
perekrutan terjadi persaingan antara KPPS, Linmas, Saksi partai politik dan Caleg, serta PTPS itu sendiri. Tentu masyarakat memiliki pertimbangan tersendiri untuk memilih melibatkan diri dalam gelaran pemilu pada porsi yang mana, mulai dari pertimbangan pendapatan, beban tugas dan fungsi hingga kompetensi.

Dengan pola rekrutmen yang terkesan terburu-buru, keterbatasan sumber daya manusia, beban kerja PTPS yang cukup berat dan ditambah dengan persyaratan teknis yang sulit diterapkan, menyebabkan kinerja Bawaslu terhambat dan dalam beberapa kasus malah terbukti melakukan pelanggaran kode etik. Rekrutmen yang seharusnya menghasilkan petugas PTPS yang handal, berkompetensi, dan netral malah hanya menghasilkan PTPS dengan kualitas apa adanya. Bahkan di banyak kasus, Panwascam harus melakukan 'jemput bola' agar kuota PTPS terpenuhi dan berimbas pada kualitas pengawasan pada tingkatan bawah.

Sementara Bawaslu sebagai lembaga pelaksana Undang-Undang Pemilu tidak bisa melakukan banyak inovasi dalam hal perekrutan serta terpaku pada mekanisme yang sudah diatur. Hasilnya, mereka yang menjadi petugas PTPS banyak yang tidak memahami teknis pemungutan suara. Problemnya, PTPS sebagai ujung tombak pengawasan Pemilu hanya diberikan sekali Bimtek pasca dilantik sebagai petugas PTPS yang berimbahs pada pengetahuan teknis pemilu. KIPP mencatat bahwa kehadiran PTPS ternyata tidak mengurangi berbagai pelanggaran dan penyimpangan dalam proses pungut hitung, sebagaimana yang diakui oleh Bawaslu sendiri. Sehingga menurut KIPP Bawaslu perlu melakukan evaluasi terhadap kinerja PTPS yang belum mampu meningkatkan kualitas pelaksanaan pungut hitung suara di TPS.

\section{Metode Penelitian}

Tipe penelitian ini adalah kualitatifdeskriptif. Dalam penelitian ini, informan diarahkan untuk dapat menggambarkan/ menceritakan secara rinci permasalahan dalam rekrutmen penyelenggara pengawas pemilu di tingkat bawah yakni PTPS serta berbagai persoalan yang melingkupinya, termasuk faktorfaktor internal maupun eksternal yang mendukung maupun menghambat kinerja mereka. Penelitian ini juga mempertimbangkan peran subyektif dari setiap informan dalam memperoleh informasi. Dengan kata lain, sisi "emic" lebih ditonjolkan dengan mendeskripsikan informasi yang diperoleh berdasarkan pada pernyataan, pola pikir dan interpretasi informan sehingga akan dapat diungkap data tersembunyi.

Penelitian ini dilakukan di dua kecamatan yang ada di Kabupaten Deliserdang, Sumatera Utara yakni Kecamatan Percut Sei Tuan dan Kecamatan Sunggal. Pemilihan lokasi dianggap menarik sebab kedua Kecamatan tersebut memiliki jumlah TPS yang banyak, masing-masing 814 dan 1250 TPS. Selain itu, kondisi sosial-ekonomi masyarakat yang beragam baik dari sisi tingkat pendidikan hingga mata pencaharian akan berpengaruh terhadap proses rekrutmen PTPS yang ada di kedua kecamatan tersebut.

Studi literatur juga menjadi kerangka acuan sebagai bahan komparasi dalam perspektif ilmu politik. Sumber data dari pemberitaan dari media cetak maupun 
elektronik sangat membantu dalam usaha mencari jejak informasi mengenai PTPS. Adapun dalam penelitian ini penulis berusaha menelusuri perjalanan pembentukan PTPS mulai dari tahap perekrutan sampai pembubaran dengan melihat setiap permasalahan yang hadir.

\section{Perspektif Teori}

Joan E. Pynes dalam bukunya Human Research Management for Public \& Non Profit Organization menyatakan, Recruitment is the process of attracting qualified candidates to apply for vacant positions within an organization. Rekrutmen SDM merupakan sebuah proses dalam menarik calon-calon yang memiliki kualifikasi untuk masuk ke posisi di dalam organisasi. Sedangkan R Wayne Mondy perekrutan adalah proses menarik orang - orang pada waktu yang tepat, dalam jumlah yang cukup, dan dengan persyaratan yang layak, untuk mengisi lowongan dalam organisasi. Berdasarkan pendapat diatas dapat dikatakan bahwa rekrutmen SDM adalah upaya dalam menarik calon SDM yang memenuhi kualifikasi atau persyaratan yang telah ditentukan untuk menempati posisi tertentu dalam sebuah organisasi.

Rekrutmen merupakan proses yang dilakukan perorangan, organisasi, lembaga, dan perusahaan untuk menarik atau mencari pekerja dalam jumlah dan waktu tertentu guna membantu menjalankan sebuah proses untuk mencapai tujuannya. Rekrutmen juga merupakan sebuah langkah awal orgnisaai untuk menjaring anggota yang berkualitas dan sesuai dengan kebutuhan organisasi tersebut. Artinya rekrutmen merupakan sebuah proses untuk mencari karyawan atau anggota yang berkualitas dan ahli di bidangnya.

Armstrong (2014) menjelaskan rekrutmen SDM merupakan salah satu bagian dari proses mengelola SDM mulai dari menentukan kebutuhan kerja hingga hubungan dan pelayanan karyawan. Rekrutmen SDM berfungsi untuk mengenali calon SDM yang memenuhi standar kualifikasi yang dibutuhkan dan menariknya menjadi SDM dalam sebuah organisasi.

Menurut R Wayne Mondy, salah satu tahapan yang penting dalam proses rekrutmen adalah perencanaan SDM yang dibutuhkan baik secara kuantitas atau kualitas dalam sebuah perusahaan atau organisasi. Kebutuhan ini didasarkan atas alternatif - alternatif evaluasi dari penarikan karyawan yang ada. Jika terdapat evaluasi dalam penarikan karyawan yang ada maka perekrutan akan dimulai dilakukan. Permintaan rekrutmen SDM akan dimulai dengan manajer mengeluarkan permintaan karyawan (employee requisition) berupa dokumen yang merinci nama pekerjaan, departemen, tanggal karyawan dibutuhkan kerja, dan selainnya.

Setelah menyusun kebutuhan akan kuantitas dan kualitas SDM, langkah berikutnya mencari sumber-sumber calon karyawan yang memenuhi syarat yang telah ditetapkan. Sumber calon karyawan ada 2 , yaitu dalam perusahaan (sumber internal), di luar perusahaan (sumber eksternal). Perekrutan eksternal diperlukan untuk mengisi pekerjaan tingkat pemula (entry level), mendapatkan keterampilan ketrampilan yang belum dimiliki SDM yang ada, dan memperoleh SDM dengan latar belakang yang berbeda untuk menciptakan keragaman ide. 
Proses rekrutmen atau penyeleksian harus dilakukan sebaik mungkin agar tidak terjadi kesalahan dalam menerima dan menempatkan tenaga kerja, hal ini harus dilakukan dengan baik dan teliti untuk menghindari pekerja yang tidak dapat memenuhi target yang telah ditetapkan oleh perusahaan. Pendapat lain mengungkapkan bahwa rekrutmen adalah proses untuk menjaring para pelamar kerja yang mempnyai spesifikasi tertentu, yang memenuhi syarat sebagai pekerja dalam perusahaan, badan atau lembaga seperti diungkapkan pendapat ahli di bawah ini:

"Succesful human resource planning is designed to identify an organization's human needs. Once this needs are known, an organization will want to do something about meeting them. The next step, them, in the staffing function-assuming, of course, that demand for certain skills, knowledge, and abilities as greater than the currwnt supply- is recruitng "(Decenzo \& Robbins, 1999:156)

\section{Hasil dan Pembahasan}

Pemilu 17 April 2019 dikatakan sebagai pemilu yang paling rumit dan menakjubkan di dunia karena skalanya yang besar dan dilaksanakan dalam satu hari saja. Dengan jumlah pemilih sebanyak 193 juta orang, Indonesia berhasil memadukan antara pemilihan legislatif (Pileg) dan pemilihan presiden (Pilpres). Pemungutan suara dilaksanakan pada 809.500 tempat pemumgutan suara (TPS), di mana setiap TPS melayani sekitar 200 hingga 300 orang/DPT pada saat hari pencoblosan (Jawapos, 2018). Artinya, jumlah TPS meningkat dari Pemilu 2014 yang hanya berjumlah 500.000 dengan melayani 400 orang per TPS-nya. Efisiensi di TPS inilah yang menjadi salah satu kunci keberhasilan terlaksananya pemilu di Indonesia.

Selain itu, yang unik dalam pemilu di Indonesia adalah dilaksanakan secara manual yakni mencoblos dan dihitung pula secara manual berjenjang. Sementara partisipasi pada pemilu serentak 2019 melampaui angka persentase yang ditargetkan yaitu mencapai 81 persen. Angka partisipasi ini naik dari pemilu 2014 dengan 70 persen partisipasi untuk pemilihan presiden dan 75 persen untuk pemilihan legislatif (KPU.go.id, 2019).

Mengingat betapa kompleksnya Pemilu Serentak 2019 baik secara substansial maupun prosedural, mengharuskan dihadirkannya Pengawas pemilu ditingkatan yang paling bawah. Kehadiran PTPS sebagai ujung tombak pengawasan Pemilu dibawah Bawaslu menjadi satu solusi agar pemilu berjalan dengan efektif, berkeadilan dan berintegritas. Data Bawaslu menunjukkan dari sekian banyak pelanggaran pidana pemilu mulai dari netralitas aparat dan birokrat negara, kampanye, penggunaan fasilitas negara, dan lain sebagainya, ada satu yang paling mendominasi yakni politik uang dengan 23 putusan inkrah. Tentu angka ini tidak sebanyak pada kenyataan di lapangan terkait intrik politik uang yang dampaknya langsung dirasakan oleh masyarakat pemilih yang ada di bawah.

Politik uang sudah terkonfirmasi sebagai rahasia umum masyarakat di tingkatan bawah untuk memengaruhi pilihan dalam gelaran pesta demokrasi. Ini sebagai alasan mengapa PTPS begitu relevan sebagai ujung tombak pengawasan 
selama gelaran pesta demokrasi di wilayah akar rumput, selain daripada fungsi pengawasan langsung di TPS dan pengawasan adminsitrasi lainnya.

\subsection{Ideal menjadi seorang Pengawas TPS}

Menurut Stoner dan Freeman (1989: 556) yang dikutip oleh Wasistiono dan Yonatan (2009), dikatakan bahwa pengawasan merupakan proses untuk menjamin suatu kegiatan sesuai dengan rencana kegiatan. Sedangkan Koontz (1994) berpendapat bahwa pengawasan adalah pengukuran dan tindakan atas kinerja yang berguna untuk meyakinkan organisasi secara obyektif dan merencanakan suatu cara dalam mencapai tujuan organisasi.

Tentu dalam konteks pemilu pengawasan merupakan usaha yang dilakukan demi terciptanya keadilan dalam pemilu. Dalam Pasal 22E ayat (1) Undang-Undang Dasar Negara Republik Indonesia Tahun 1945 dinyatakan, pemilihan umum dilaksanakan secara langsung, umum, bebas, rahasia, jujur dan adil setiap lima tahun sekali. Sesuai ketentuan tersebut, "adil" merupakan salah satu asas penyelenggaraan pemilu. Oleh karena itu, asas tersebut haruslah menjiwai sistem pemilu yang terdiri dari hukum pemilu (electoral law) maupun proses penyelenggaraan pemilu (electoral process). Yang dimaksud dengan pengawasan pemilu adalah kegiatan mengamati, mengkaji, memeriksa, dan menilai proses penyelenggaraan pemilu sesuai peraturan perundang-undangan (dikutip dari Perbawaslu No. 2 Tahun 2015).

Pengawasan pemilu bertujuan memastikan terselenggaranya pemilu secara langsung, umum, bebas, rahasia, jujur, adil, dan berkualitas, serta dilaksanakannya peraturan perundangundangan mengenai pemilu secara menyeluruh; mewujudkan pemilu yang demokratis; dan menegakkan integritas, kredibilitas penyelenggara, transparansi penyelenggaraan dan akuntabilitas hasil pemilu.

Dalam kerangka itu kemudian keadilan pemilu dapat terwujud yang mencakup sarana dan mekanisme serta mengandung tiga elemen, yaitu pencegahan terhadap sengketa pemilu (prevention of electoral disputes), penyelesaian terhadap sengketa pemilu (resolution of electoral disputes), dan alternatif penyelesaian sengketa pemilu di luar mekanisme yang ada (alternative of electoral disputes). (Ayoeb \& Ellis, 2010). Di pundak PTPS lah fungsi pengawasan dan pencegahan yang paling mendasar berjalan dan PTPS musti memiliki kapasitas mumpuni dalam mengemban tugasnya sebagai ujung tomnbak pengawasan dalam pemilu di Indonesia.

Secara garis besar ada 6 poin ruang lingkup tugas PTPS, 1) pengawasan sebelum pemungutan suara; 2 ) pengawasan persiapan pemungutan suara; 3) pengawasan pemungutan suara; 4) pengawasan proses pemungutan suara; 5) pengawasan penghitungan surat suara, dan; 6) pemungutan suara ulang dan penghutungan ulang surat suara. Seorang PTPS yang ideal harus mengetahui sekaligus melaksanakan tugas tersebut dengan penuh integritas dan profesional. PTPS diwajibkan melakukan fungsi koordinasi dengan KPPS sekaligus melakukan pengawasan terhadap KPPS itu sendiri. Jadi tidak hanya melakukan fungsi pengawasan kepada partai peserta pemilu dan calon legislatif, tetapi juga melakukan 
pengawasan kepada penyelenggara di bawah KPU.

Tidak berhenti hanya disitu, PTPS juga musti memahami administrasi pemungutan suara pada saat hari pemungutan suara, mulai dari pemeriksaan TPS, pemasangan salinan daftar pemilih dan daftar calon, pengawasan saksi, hingga pengawasan penyampaian salinan DPT, DPTb kepada saksi peserta pemilu dan PTPS. Fungsifungsi tersebut tentu bukan tugas yang sederhana. Seorang PTPS harus mengetahui secara detail sekaligus berani mempraktekkan tugasnya bila ada kesalahan atau pelanggaran yang dilakukan baik oleh penyelenggara pemilu maupun peserta pemilu.

\subsection{Kendala dalam Proses Rekrutmen PTPS}

Kompleksitas tugas dan fungsi pengawasan yang dilimpahkan kepada PTPS inilah yang membuat masyarakat ragu untuk terlibat menjadi seorang pengawas pemilu pada level paling bawah tersebut. Kenyataan bahwa PTPS dibutuhkan dalam upaya mewujudkan Pemilu berintegritas dan berkeadilan mengaami kendala, mulai dari proses rekrutmen, implementasi tugas pokok dan fungsi, hingga kapasitas PTPS.

Bila dibandingkan dengan Pemilu 2014 jumlah pelanggaran Pemilu Serentak 2019 mengalami kenaikan. Bawaslu mencatat ada 15.052 jumlah pelanggaran Pemilu. Jumlah ini hampir 50\% naik dari pemilu sebelumnya yang tercatat hanya 10.754 jumlah pelanggaran. Setidaknya ada dua hal yang membuat catatan pelanggaran Pemilu begitu tinggi yakni pengawasan yang ketat sehingga lebih banyak pelanggaran yang terpantau dan dilaporkan, dan yang kedua peserta Pemilu yang masih tidak taat terhadap peraturan kampanye.

Dalam artian, pada Pemilu 2019, Bawaslu dan jajaran dibawahnya berhasil menaikkan fungsi penindakan terhadap pelanggaran pemilu. Tetapi musti diingat bahwa, Bawaslu RI hingga pada tingkatan PTPS tidak hanya berkutat pada fungsi penindakan dan peradilan saja, namun juga pada fungsi pencegahan. Setelah dikonfirmasi, banyak petugas PTPS yang tidak memahami fungsi pencegahan tersebut. Dan kalaupun petugas PTPS paham, banyak diantara mereka yang enggan melakukannya dengan alasan kekerabatan dan kedaerahan. ${ }^{3}$

Kualitas petugas pengawas Pemilu yang terkesan apa adanya tersebut merupakan cerminan betapa proses rekrutmen tidak berjalan sesuai dengan yang diharapkan. Regulasi menjadi permasalahan yang dominan, dan Bawaslu sebagai lembaga pelaksana Undang-Undang harus taat dengan apa yang sudah ditetapkan. Rekrutmen yang berlangsung singkat dan minimnya antusiasme masyarakat menjadikan kualitas PTPS terkesan apa adanya.

Ini yang dialami oleh Panwascam di Kecamatan Sunggal dan Kecamatan Percut Sei Tuan. Dengan jumlah TPS yang besar dengan masing-masing jumlah 814 dan 1250 TPS mengharuskan mereka bekerja ekstra untuk memenuhi kuota PTPS yang besarannya sebanding dengan jumlah TPS yang ada. Harus disadari bahwa keadaan ini akibat antusiasme masyarakat yang masih minim.

\footnotetext{
3 Dikonfirmasi dari bebebrapa petugas PTPS dan Panwascam Kecamatan Sunggal dan Percut Sei Tuan
} 
Hal ini dikonfirmasi Panwascam Kecamatan Sunggal dan Percut Sei Tuan, Kabupaten Deliserdang. Mereka kompak menyatakan, masyarakat punya beberapa alasan untuk menolak menjadi PTPS dan lebih memilih menjadi KPPS. Masyarakat takut akan sistem kerja yang rumit dan mengancam keselamatan mereka. Masyarakat berasumsi menjadi PTPS berarti melaporkan segala tindak kecurangan yang ada di sekitar. Artinya, permasalahan pertama yang muncul berkenaan dengan Sumber Daya Manusia yang terbatas.

Mereka mengakui proses perekrutan yang ideal tidak dapat dilakukan sebab di pengalaman Pemilu Serentak 2019 silam mereka hanya mendapatkan satu orang pendaftar di satu TPS, yang artinya tidak ada proses seleksi ketat didalamnya. Panwascam bahkan harus menempatkan seorang PTPS di TPS yang bukan menjadi tempat ia mencoblos. Hal ini dikarenakan ada TPS yang tidak punya wakil yang mendaftar sebagai PTPS, dan ada pula dalam satu TPS jumlah yang mendaftar lebih dari satu.

Maka jumlah yang lebih dari satu tersebut kemudian diterima oleh Panwascam untuk menutupi TPS yang tidak memiliki PTPS. Permasalahan yang muncul saat kondisi ini terjadi adalah PTPS yang DPT-nya berada di TPS lain akan kesulitan menyalurkan hak suaranya, sebab PTPS bekerja penuh mengawasi TPS dari mulai persiapan, pemungutan hingga penghitungan suara. Sedangkan KPU tidak memiliki regulasi tentang pindah memilih (A5) antar desa/kelurahan. Pada akhitnya perekrutan PTPS tidak berjalan profesional bahkan dalam beberapa kasus terkesan bersifat patronase.
Permasalahan kedua terkait rekrutmen PTPS yang sangat singkat dan menyebabkan persiapan terhadap PTPS menjadi terbatas. Sebagaimana diketahui, rekrutmen PTPS dimulai dari proses pendaftaran selama 4 hari, dilanjutkan dengan seleksi berkas selama sekitar 3 minggu sebelum 23 hari menuju hari pemungutan suara, dan pengumunan lolos 5 hari sebelum 23 hari masa pencoblosan. Setelah Panwascam selesai melakukan perekrutan, dilanjutkan dengan pelantikan dan Bimbingan Teknis yang hanya dilakukan dalam waktu sehari oleh Panwascam setempat.

Selanjutnya, wilayah yang luas dan jumlah TPS yang banyak menjadi tantangan tersendiri. Untuk Kecamatan Percut Seituan Luas wilayahnya yakni 190,79 Km2 dengan DPT 229.979 orang, dan luas wilayah Kecamatan Sunggal sebesar 92,52 Km2 dengan DPT 177.187 orang. Keduanya terbesar di Kabupaten Deliserdang baik secara luas geografis maupun jumlah penduduk dan DPT dengan latar belakang mata pencaharian mayoritas Pekerja/buruh, petani, pedagang dan nelayan. Luasnya wilayah ini sangat memengaruhi peforma Panwascam dalam merekrut PTPS. Pasalnya, waktu yang disediakan untuk melakukan perekrutan terlampau singkat apabila dibandingkan dengan jangkauan daerah dan jumlah PTPS yang harus dihadirkan pada masing-masing TPS.

Dikonfirmasi oleh Panwascam kedua Kecamatan, jumlah penduduk yang besar tidak kompatibel dengan ketersediaan SDM yang sesuai dengan persyaratan perekrutan PTPS. Diakui bahwa antusisme banyak datang dari kalangan muda mahasiswa/mahasiswi, 
tetapi karena alasan usia mereka tidak bisa mendaftar sebagau PTPS. Rata-rata mereka yang secara usia memenuhi syarat sudah memiliki rutinitas dan mapan bekerja sehingga tidak tertarik untuk menjadi PTPS, dan lebih memilih menjadi KPPS karena waktu kerja yang singkat, mekanisme kerja yang simpel dan sudah terbiasa serta bekerja secara berkelompok.

Mau tidak mau Panwascam tidak melakukan fungsi rekrutmen secara efisien dan tanpa proses ketak untuk mendapatkan SDM yang unggul di bidang pengawasan dan kepemiluan. Hal ini menjadi problematis apabila dihadapkan dengan pembekalan pengetahuan seputar pengawasan yang dikemas didalam Bimbingan Teknis (Bimtek) yang hanya dilakukan sehari pasca pelantikan. Bagaimana mungkin Panwascam dalam waktu sehari bisa secara efektif membekali pengetahuan dan sikap independensi PTPS dalam waktu sehari? Dengan latar belakang pendidikan yang berbeda-beda, diakui bahwa kapasitas PTPS sangat jauh dari yang diharapkan. Bimbingan teknis menjadi semacam seremonial saja. Padahal seorang PTPS tidak cukup hanya dibekali pengetahuan seputar pengawasan dalam Pemilu, lebih jauh lagi, PTPS membutuhkan pendampingan psikologis dan pola komunikasi yang sesuai untuk menunjang kinerja pengawasan di lapangan.

Sebab PTPS akan berhadapan dengan berbagai dinamika baik intrik kecurangan maupun kesalahan di TPS. Hal ini dibutuhkan agar PTPS mampu secara cakap dan meyakinkan menyampaikan kepada Petugas TPS, peserta Pemilu maupun masyarakat bahwa terjadi kesalahan/pelanggaran di tingkat TPS. Banyak kejadian kesalahan dan pelanggaran hanya diselesaikan dengan cara-cara musyawarah di tingkat TPS. Ada dua kemungkinan, yang pertama seorang PTPS tidak tahu apakah satu kejadian di TPS termasuk kesalahan/ pelanggaran atau bukan. Dan yang kedua, kalaupun PTPS melihat itu adalah sebuah kesalahan, ia tidak berani melakukan upaya penindakan langsung, sebab secara psikologis seorang PTPS tidak memiliki keberanian untuk mengungkapkan bahwa telah terjadi kesalahan/kecurangan di TPS tersebut.

Kendala-kendala di lapangan mau tidak mau menghasilkan PTPS tidak bekerja secara maksimal. Dari hasil temuan, terbukti sebagian PTPS yang dihasilkan memiliki integritas dan kapasitas yang lemah dan malah menimbulkan permasalahan seperti:

1. Netralitas dan sikap independensi. Hasil temuan di lapangan, dan dikonfirmasi oleh beberapa petugas PTPS sendiri, sebagian dari mereka terlibat menjadi tim sukses salah satu Caleg tertentu baik melalui pola patronase maupun kekerabatan.

2. Pengetahuan yang lemah mengenai Tugas Pokok dan Fungsi dan tidak memahami jenis pelanggaran pemilu dan mekanisme pencegahan.

\subsection{Rekrutmen dan Kompensasi PTPS}

Kompensasi adalah salah satu cara untuk meningkatkan produktifitas kerja, motivasi kerja, prestasi kerja dan kepuasan kerja seorang petugas PTPS. Sebagaimana kita ketahui penetapan kompensasi adalah salah satu diantara fungsi operasional manajemen personalia instansi yang sangat penting. Oleh 
karena itu kompensasi harus mempunyai dasar yang logis, rasional dan dapat dipertahankan karena hal ini menyangkut faktor yang mempengaruhi emosional dari sudut pandang petugas PTPS.

Pemberian kompensasi bukan hanya dapat memotivasi atau mendorong seseorang untuk menjadi pekerja/petugas, tetapi juga karena kompensasi yang diberikan akan mempengaruhi semangat dan kegairahan kerja. Kebutuhan akan pendapatan dan keinginan mereka perlu diperlakukan secara wajar oleh negara yang membuat program kompensasi menjadi vital bagi departemen sumber daya manusia. Setelah PTPS bekerja dan memberikan kontribusi yang strategis bagi instansi, maka sudah selayaknya instansi tersebut memberikan suatu imbalan bentuk kompensasi.

Setelah ditelisik, baik melalui Panwascam maupun petugas PTPS, minimalnya kinerja dan dan antusiasme masyarakat untuk menjadi petugas PTPS dikarenakan kompensasi yang tidak sesuai dengan beban kerja. Diketahui honorarium PTPS sejumlah 600 ribu rupiah. Beberapa petugas PTPS menyebutkan menjadi PTPS hanya dihitung sebagai kerja sampingan saja. Integritas dan independensi menjadi nomor dua yang bisa ditawar.

\section{Evaluasi Pola Rekrutmen PTPS dan Upaaya yang bisa dilakukan}

Di atas telah diuraikan permasalahan dan kendala yang dihadapi Panwascam dan dampaknya terhadap PTPS terkait dengan rekrutmen yang dilakukan. Berdasarkan persoalan, ada beberapa poin yang menjadi bahan evaluasi dalam hal pola rekrutmen PTPS.
1. Secara regulasi, UU 7/2017 tentang Pemilu tidak memberikan kesempatan yang luas kepada setiap warga negara yang sudah dapat memilih dalam Pemilu 2019 dengan adanya ambang batas usia. Tidak dipungkiri bahwa setiap daerah memiliki keunikan dan sumber daya terbatas mejadi fakta yang tidak dapat dihindari. Juga terkait masa rekrutmen yang lebih diperpanjang, mengingat PTPS adalah perangkat baru dalam kepemiluan nasional.

2. Promosi dan Sosialisasi terkait kelembagaan Bawaslu, peran Bawaslu dan hadirnya PTPS pada setiap TPS. Banyak masyarakat yang belum mengetahui adanya PTPS. Sosialisasi Bawaslu ke masyarakat sangat penting dan berdampak terhadap proses rekrutmen. Selama ini mungkin Bawaslu banyak melakukan sosialisasi ke kampuskampus. Dalam upaya menaikkan eforia dan antusiasme masyarakat untuk menjadi bagian pengawas kepemiluan, Bawaslu musti turun dan menyapa langsung masarakat.

3. Pembekalan Fungsi Pengawasan yang dikemas dalam Bimbingan Teknis (Bimtek). Ini menjadi persoalan sebab PTPS menjalankan fungsi pengawasan, penindakan dan pencegahan, tetapi hanya diberikan satu kali sesi bimbingan.

4. Proses rekrutmen yang tidak dilakukan secara terbuka dengan tahapantahapan yang jelas. Proses rekrutmen justru memberikan celah nepotisme dan memungkinkan ketidakmandirian para PTPS dalam bertugas karena masih bergantung pada rekomendasi. Sebagaimana diketahui Panwascam 
untuk menunjang kinerja harus berkoordinasi dengan perangkat desa dan tokoh masyarakat agar kuota terpenuhi. Dampaknya, independensi dan integritas kalah dengan asas hutang budi karena telah diberikan akses menjadi PTPS.

Berdasarkan persoalan di atas, maka dapat disusun beberapa rekomendasi berikut sebagai upaya yang dapat dilakukan.

1. Dalam tahapan rekrutmen tersebut diadakan tahapan sosialisasi sebelum tahapan pengumuman pendaftaran. Masa sosialisasi ini dilakukan 2-3 bulan sebelum dimulainya tahapan. Untuk itu Bawaslu Kab/kota harus menyediakan anggaran sosialisi untuk turun secara langsung ke masyarakat.

2. Upaya penyebarluasan informasi tentang rekrutmen dan mempersiapkan calon- calon yang kompeten dapat melibatkan organisasi masyarakat, tokoh agama, perguruan tinggi, LSM dan para penggiat demokrasi lainnya.

3. Memperingan syarat calon PTPS. Beberapa persyaratan yang perlu ditinjau ulang antara lain, syarat usia yang semula paling rendah 25 tahun diubah menjadi minimal 18 tahun. Selain itu adalah tingkat pendidikan, karena di beberapa daerah terpencil masih sulit ditemukan tingkat pendidikan SMA.

\section{Simpulan}

Pengawasan Pemilu menjadi salah satu agenda penting dalam gelaran pemilu yang diadakan secara reguler. Tak dapat dipungkiri, bahwa tindak pidana pemilu, pelanggaran administrasi hingga permasalahan independensi penyelenggara pemilu masih banyak terjadi. Hadirnya PTPS tentu sebagai wujud kongkrit agar permasalahan pemilu dapat diminimalisir baik dari sisi penyelenggara pemilu maupun peserta pemilu. Maka menghadirkan PTPS yang berkualitas menjadi urgensi agar keadilan pemilu mampu terwujud.

Dengan permasalahan yang hadir seperti yang sudah disebutkan diatas, Bawaslu mestinya harus merespon agar eksistensi pengawasan pemilu di akar rumput meningkat dan dikenal di masyarakat. Ini penting, sebab permasalahan Bawaslu yang saat ini terjadi adalah kesulitan melakukan rekrutmen PTPS diakibatkan minimnya antusiasme masyarakat disamping cara kerja pengawasan yang kurang tersosialisasi.

Kedepan, Bawaslu mesti membuka diri dengan melakukan pendekatan intensif dengan masyarakat serta bersentuhan langsung dengan mereka. Mengajak masyarakat berpaertisipasi dalam pengawasan, baik secara struktural PTPS maupun secara individu. 


\section{DAFTAR PUSTAKA}

Amstrong, Michael (2006). A Handbook of Human Resource Management Practice, Edition London: Kogan Page

Ayoeb, A \& Ellis, A (Ed.). (2011). Electoral Justice: The International IDEA Handbook, International IDEA.

Bawaslu.go.id. (2019). Hasil Pengawasan Pemilu 2019. Diakses Dari https://www. bawaslu.go.id/id/hasil-pengawasan/pemilu-2019

Farisa, F, C. (2019, Mei 27). KPU Sebut Partisipasi Pemilih 2019 Capai

81 Persen. Kompas.com. Diakses Dari: https://nasional.kompas.com/

read/2019/05/27/16415251/kpu-sebut-partisipasi-pemilih-pada-peilu-2019-capai-81persen

Hayati, N, N. (2019, April 27). Catatan Penting atas Pemilu 2019. Kompas.com.

Diakses Dari: https://nasional.kompas.com/read/2019/04/27/17101381/catatanpenting-atas-pemilu-2019?page=all

Joan E Peyes. (1997). Human Resources Management Non Profit Organization.

Kartini, D,S. (2017). Demokrasi dan Pengawasan Pemilu. Journal of Governance

Volume 2. Univeristas Padjajaran, Bandung.

Mathis, R. L. Jackson, J. H. (2011). Manajemen Sumber Daya Manusia. Selemba Empat, Jakarta

Pradana, J. (2019, Juni 3). Sepenggal Perjalanan Kewenangan Bawaslu. Bawaslu. go.id. Diakses Dari: https://bawaslu.go.id/id/berita/sepenggal-perjalanan-

kewenangan-bawaslu

Pratama, A, N. ((2018, Juni 5). Perjalanan Terbentuknya Pengawas Pemilu, dari Panwaslak pada 1982 hingga Kini Bawaslu. Kompas.com. Diakses dari: https:// nasional.kompas.com/read/2018/06/05/21020331/perjalanan-terbentuknya-

pengawas-pemilu-dari-panwaslak-pada-1982-hingga-kini?page=all

Rudia, K. (2019, Maret 24). Dicari, Pengawas TPS "Bermata Seribu".

Baliekxpress.jawapos.com. Diakses Dari: https://baliexpress.jawapos.com/

read/2019/03/24/127268/dicari-pengawas-tps-bermata-seribu

Wawancara 20 Juli 2019. Pengawas Tempat Pemungutan Suara di Desa Bandar Klippa, Kecamatan Percut Sei Tuan, Kabupaten Deliserdang.

Wawancara 20 Juli 2019. Pengawas Tempat Pemungutan Suara di Desa Sei Semayang, Kecamatan Sunggal, Kabupaten Deliserdang.

Wawancara 20 Juli 2019. Pengawas Tempat Pemungutan Suara di Desa Sei Mencirim, Kecamatan Sunggal, Kabupaten Deliserdang.

Wawancara 21 Juli 2019. Pengawas Tempat Pemungutan Suara di Desa Amplas, Kecamatan Percut Sei Tuan, Kabupaten Deliserdang.

Wawancara 22 Juli 2019. Panitia Pengawas Kecamatan Sunggal, Kabupaten DeliSerdang, Provinsi Sumatera Utara.

Wawancara 24 Juli 2019. Panitia Pengawas Kecamatan Percut Sei Tuan, Kabupaten Deliserdang, Provinsi Sumatera Utara.

Winarno, B. (2012). Kebijakan Publik Teori, Proses, dan Studi Kasus. Yogyakarta: CAPS. 